\title{
MINERALOGICAL AND GEOCHEMICAL STUDY OF NEOGENE RED BEDS FROM MOUDANIA AND POTIDEA, CHALKIDIKI (MACEDONIA, GREECE)
}

\author{
Tsirambides A. ${ }^{1}$, Georgiadis I. K. ${ }^{1}$, Papadopoulos A. A. ${ }^{1}$, Ziafetis A. A. ${ }^{1}$, and \\ Giouri A. N. ${ }^{1}$
}

${ }^{1}$ Aristotle University of Thessaloniki, School of Geology, Department of Mineralogy-PetrologyEconomicGeology,ananias@geo.auth.gr, iogeorgi@geo.auth.gr,argpapad@geo.auth.gr, aziafeti@geo.auth.gr,agiouri@geo.auth.gr

\begin{abstract}
The Neogene red beds from Moudania and Potidea (Chalkidiki) are studied in order to find the conditions under which they were formed. They are incoherent coarse grained sands, with poorly sorted grains. Angular to sub-angular rock fragments derived from the adjacent parent rocks are very common. The red beds are texturally and mineralogically immature. Most of the samples are gravel sands. The extended presence of sand size grains $(>0.063 \mathrm{~mm})$ in the samples suggests high intensity of weathering of the parent rocks and rapid transportation and deposition of the weathered materials close to the source area. The detrital minerals present in the whole samples in decreasing abundance are quartz, feldspars (plagioclase + orthoclase), mica (+clay minerals), pyroxene, amphibole, pyrite and halite (except two samples which are rich in calcite). In the $<0.063 \mathrm{~mm}$ fraction quartz decreases greatly, while feldspars increase. The presence of illite, smectite (+illite/smectite), and chlorite (+vermiculite) in the $<0.063 \mathrm{~mm}$ fraction is evident. The most likely source minerals for the formation of the studied red beds are quartz, feldspars, micas, and various Fe-Mg silicates, which are primary constituents of the Mesozoic basement igneous and metamorphic rocks predominating in the adjacent area. In the poorly drained lowland of the studied area mean annual air temperature is $16.2^{\circ} \mathrm{C}$, mean annual humidity $75 \%$, and mean annual rainfall $59.5 \mathrm{~cm}$. The samples may be considered ferromagnesian and potassic sandstones. The felsic igneous provenance signature is justified for most of the samples. The climate under which these Neogene red beds were formed was warm and semiarid.
\end{abstract}

Key words: poorly sorted sands, red beds, Moudania, Chalkidiki (Greece).

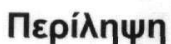

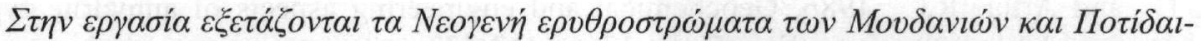

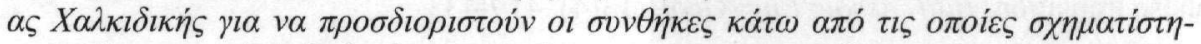

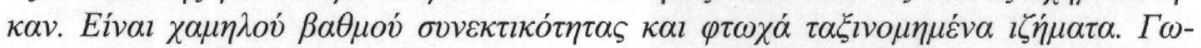

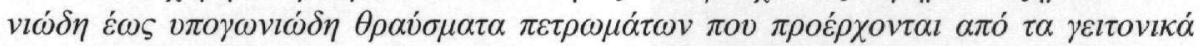

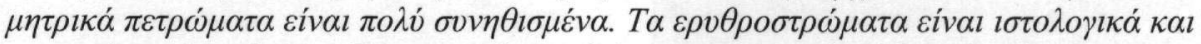

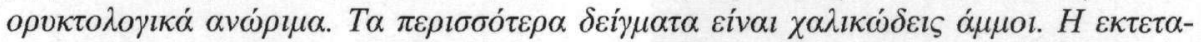

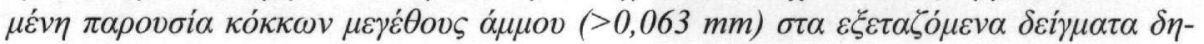




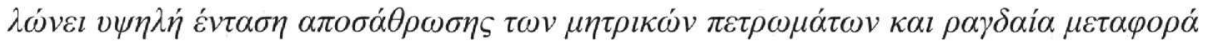

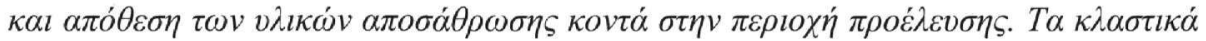

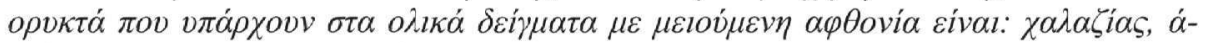

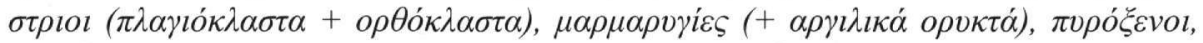

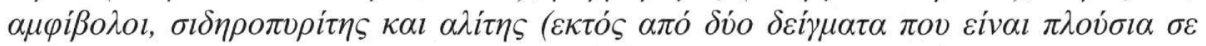

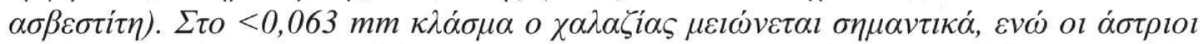

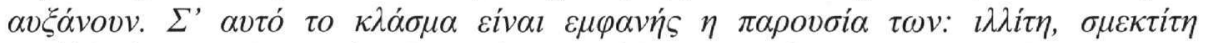

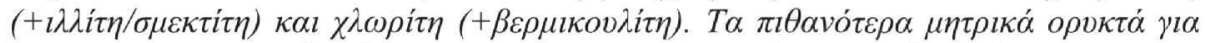

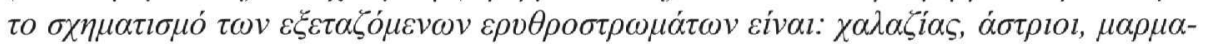

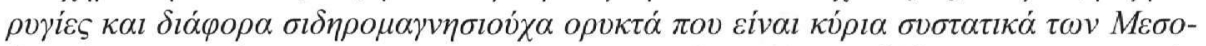

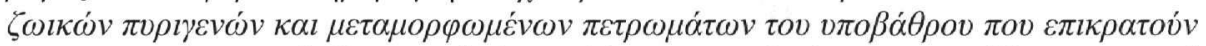

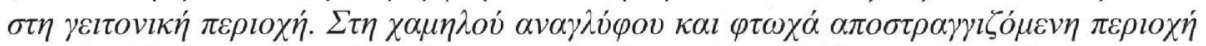

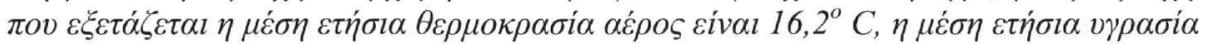

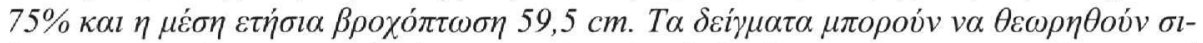

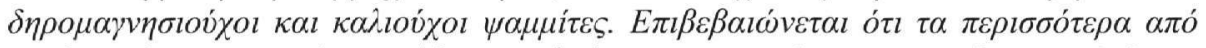

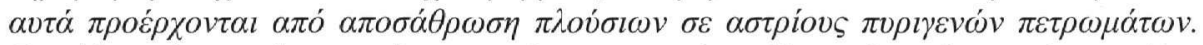

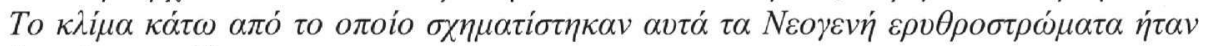

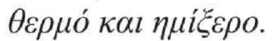

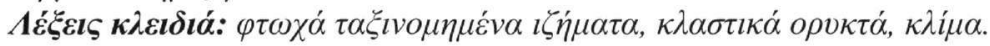

\section{Introduction}

Red beds are sedimentary rocks deposited on land under a strongly oxidizing environment. They may be composed of breccias, sandstones, siltstones and claystones and are predominantly red in colour due to the presence of ferric oxide (mainly tiny hematite crystals), which coat individual grains. The main source of iron in the pigment is the in-place alteration of iron-rich primary minerals such as amphiboles, pyroxenes, chlorites, epidote, biotite, etc. (Walker 1976). In middle latitude regions mild temperatures, rainfall ranging from $50 \mathrm{~cm} / \mathrm{y}$ to $100 \mathrm{~cm} / \mathrm{y}$, and chemical weathering predominate (Chamley 1989). The resulting soils typically exhibit a brown colour that tends to become reddish in the warmer areas (i.e. red Mediterranean soils).

The Neogene red beds of the studied area belong to the arkosic facies and their depositional environment is fluvial-lacustrine (Psilovikos 1984). The sedimentary facies of these red beds varies from place to place, even in the same graben of Moudania-Potidea. The basic facies of the redbeds is a rhythm, composed of three individual beds with total thickness up to $30 \mathrm{~m}$ (Psilovikos et al. 1987):

- A lower bed of coarse clastics, mainly gravel (pebbles with sand matrix).

- A middle bed of sand, interbedded with gravel and silt.

- An upper bed of silt-clay, interbedded with sand.

The area of Northern Greece is a complex of grabens and horsts (mountains) arranged in a primary NW-SE trend. Intermountaineous high level basins (i.e. Ptolemais-Florina) with elevation 400-500 $\mathrm{m}$ or low level basins (i.e. Mygdonia) with elevation 150-250 m, large coastal basins and plains (i.e. Axios-Thessaloniki, Serres-Strymon) were filled with Neogene and Quaternary sediments (Psilovikos et al. 1987). The most characteristic of them are red beds. They are continental, terrestrial-fluvial clastic sediments of red-brown colour that are exposed along basin sides, at surface, or can be traced in the central parts of the basins, in the subsurface by drilling. The widespread red beds and the associated rich mammalian fauna offer a good basis for stratigraphic and paleogeographic correlation with other sedimentary deposits in the Mediterranean (Psilovikos et al. 1987).

Red soils are generally considered the result of intense mineral weathering under subtropical and tropical climates. Therefore, the terra rossa that occur under temperate climates have been consid- 
ered relict soils, formed under warmer paleoclimates (Chamley 1989, Weaver 1989). More recently red beds are interpreted as evidence of seasonally dry conditions (Sheldon 2005).

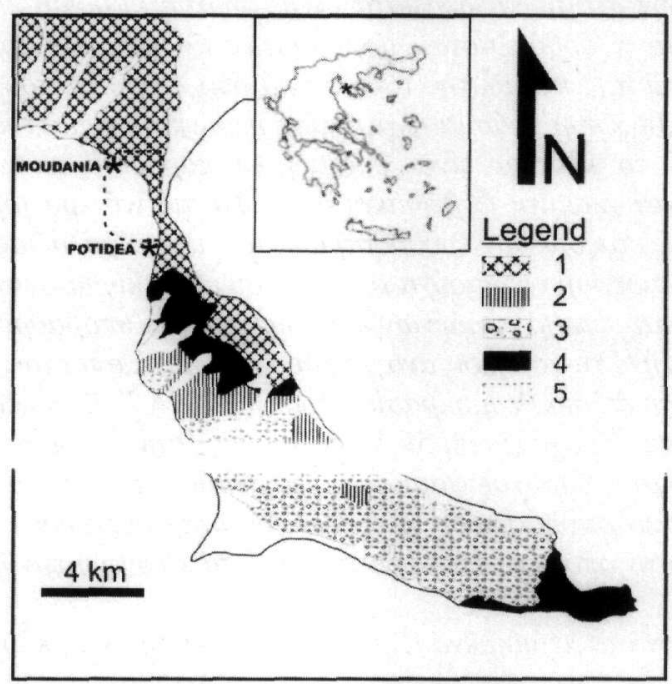

Figure 1 - Petrographic sketch map of the study area (modified from Mountrakis et al. 1993). 1=Moudania Formation (Upper Pliocene), 2=Trilofos Formation (Upper Miocene), 3=Antonios Formation (Middle-Upper Miocene), 4=Pre-Neogene bedrock, 5=sampling area

In this paper a detailed mineralogical and chemical study of the Neogene red beds from Moudania and Potidea Chalkidiki is performed. Using a variety of petrographic, mineralogical and geochemical techniques it is attempted to elucidate the processes and the climatic conditions under which these clastic sediments were formed.

\section{Geological Setting}

The study area is located eastern of the city of Moudania and geotectonically belongs to the Peonia zone, the basement of which is composed of a great variety of Mesozoic rocks (Fig. 1). In detail, the alpine basement is composed of granodiorites, diorites, gabbros, dunites, peridotites, pyroxenites, gneisses, phyllites, schists and limestones (I.G.M.E. 1978, Mountrakis et al. 1993). These basement rocks are obviously covered by Tertiary sediments. The study area is part of the elongated Axios-Thermaikos basin with a width of 10-20 km and general direction NNW-SSE, spreading from the Hellenic-Fyrom border to Kassandra Peninsula. In this basin Neogene and Quaternary terrigenous, fluvial and lacustrine sediments were deposited, unconformably overlaying the alpine basement. Lacustrine limestones have been deposited on top of them. The Neogene red beds studied occur with thickness up to $30 \mathrm{~m}$; locally, they contain carbonate lenses with length up to $20 \mathrm{~m}$.

The Moudania sediments are enlisted with the synonymous Formation where red beds are widespread. This Formation is constituted of alternations of beds of breccias, sandstones, siltstones and claystones. These sediments were deposited in a fluvial environment under intense pedological processes and oxidizing conditions (Syrides 1990). The upper part of Moudania formation is covered by Pleistocene lacustrine limestones (I.G.M.E. 1978). Syrides (1990) and Mountrakis et al. (1993) designate the age of Moudania red beds in Upper Pliocene.

\section{Materials and methods}

The samples studied were collected from well-exposed red bed outcrops and were analyzed in detail using petrographic (stereoscope and microscope), X-ray diffraction (XRD) and geochemical techniques. Prior to mineralogical analysis the samples were disaggregated by use of an agate mor- 
tar and pestle. Disaggregation was done gently in order to retain, to the extent possible, the intrinsic grain sizes of the samples. Then, they were separated into consecutive size fractions by sieving (Table 2). X-ray diffraction was performed on a Philips diffractometer with Ni-filtered $\mathrm{CuK}_{\alpha}$ radiation. Both randomly oriented powdered samples of the whole untreated sediments and filmed samples of the $<0.063 \mathrm{~mm}$ fraction with preferred orientation were scanned over the interval $3-43^{\circ} 2 \theta$ at a scanning speed $1^{\circ}$ per minute and $35 \mathrm{kV}$. Semi-quantitative estimates of the amounts of quartz, plagioclase, orthoclase, mica (+total clays) and calcite, as well as of the amphibole, pyroxene, pyrite and halite, are based on peak heights and intensity factors on XRD patterns of randomly oriented powder samples, using the methods of Schultz (1964) and Cook et al. (1975), respectively. XRD patterns taken from preferentially oriented samples were used for the semi-quantitative estimation of clay mineral phases using specific reflections and intensity factors (Moore and Reynolds 1997).

Part from each sample was taken and ground by the use of a wolfram mortar and pestle. Two grams of each powdered sample were used for the geochemical analysis. X ray fluorescence was performed on an ARL-980 apparatus whereas the alkalis were quantitavely determined with flame

\section{Results}

\subsection{Granulometry}

All the samples are coarse grained sands, poorly sorted and incoherent (except sample M7) and present red to red-brown colour because of the presence of iron oxides (mainly hematite). Angular to sub-angular rock fragments derived from the adjacent parent rocks are very common. Sample M6 contains abundant carbonate clasts and sample M7 is an arkosic limestone. All the samples are characterized by great lithological variety. The studied red beds may be characterized as immature, both texturally and mineralogically (Tables 2,3 ). The SW Chalkidiki red beds are texturally immature and very poorly sorted, with angular grains of medium grained sand size (Vazoura 1985). According to Folk et al. (1970) classification most of the samples are gravel sands. According to the Unified Soil Classification System (ASTM D 2487, 1985) the studied red beds belong to the poorly sorted sands (group symbol SP), except two (M4 and M6) which belong to the poorly sorted gravels (group symbol GP). Table 1 presents the classification of the samples studied.

Table 1 - Lithological (wt. \%) and soil classification of the samples analyzed

\begin{tabular}{|c|c|c|c|c|c|}
\hline Sample & Gravel & Sand & Silt+Clay & Class $^{1}$ & Class $^{2}$ \\
\hline M1 & 25 & 74 & 1 & gS & SP \\
\hline M2 & 5 & 93 & 2 & $(\mathrm{~g}) S$ & SP \\
\hline M3 & 25 & 70 & 5 & gS & SP \\
\hline M4 & 69 & 29 & 2 & sG & GP \\
\hline M5 & 20 & 76 & 4 & gS & SP \\
\hline M6 & 55 & 44 & 1 & sG & GP \\
\hline M7 & & & & & \\
\hline M8 & 2 & 94 & 4 & S & SP \\
\hline
\end{tabular}

' according to Folk et al. (1970), ${ }^{2}$ according to Unified Soil Classification System (ASTM D 2487) (1985), ${ }^{3}$ arkosic limestone

The grain size distribution of the samples disaggregated after gentle grinding and after sieving is given in table 2 . The extended presence of sand size grains $(>0.063 \mathrm{~mm})$ in the samples suggests high intensity of weathering of the parent rocks and rapid transportation and deposition of the weathered materials close to the source area. 
Table 2 - Grain size (mm) distribution (wt. \%) of the samples analyzed

\begin{tabular}{|c|c|c|c|c|c|c|c|c|}
\hline Sample & $\mathbf{> 4}$ & $\mathbf{4 - 2}$ & $\mathbf{2 - 1}$ & $\mathbf{1 - 0 . 5}$ & $\mathbf{0 . 5 - 0 . 2 5}$ & $\mathbf{0 . 2 5 0 - 0 . 1 2 5}$ & $\mathbf{0 . 1 2 5 - 0 . 0 6 3}$ & $<\mathbf{0 . 0 6 3}$ \\
\hline M1 & 17 & 8 & 13 & 29 & 29 & 2 & 1 & 1 \\
\hline M2 & & 3 & 8 & 29 & 50 & 5 & 3 & 2 \\
\hline M3 & & 25 & 17 & 16 & 21 & 6 & 10 & 5 \\
\hline M4 & 62 & 7 & 10 & 8 & 6 & 2 & 3 & 2 \\
\hline M5 & & 20 & 12 & 24 & 27 & 6 & 7 & 4 \\
\hline M6 & 32 & 23 & 24 & 13 & 5 & 1 & 1 & 1 \\
\hline M7 & & & & & & & & \\
\hline M8 & & 2 & 17 & 30 & 28 & 8 & 11 & 4 \\
\hline
\end{tabular}

'arkosic limestone.

\subsection{X-ray mineralogy}

The results of XRD analysis of the samples are given in table 3 . The detrital minerals present in the whole samples in decreasing abundance are quartz, feldspars (plagioclase + orthoclase), mica (+clay minerals), pyroxene, amphibole, pyrite and halite (except samples M6 and M7 which are rich in calcite). In the $<0.063 \mathrm{~mm}$ fraction quartz decreases greatly, while feldspars increase. The presence of illite, smectite (+illite/smectite), and chlorite (+vermiculite) in the $<0.063 \mathrm{~mm}$ fraction is evident. From the correlation of stereoscopic and XRD analysis sample M6 may be characterized as calcilithite and sample M7 as arkosic limestone. Dolomite was not detected in any sample. Almost in all samples (except M7) the plagioclases predominate over the K-feldspars, characteristic of immature mineralogically sediments. Also, this immaturity is confirmed by the presence of ferromagnesian minerals in all samples.

Table 3 - Mineralogical composition (wt. \%) of the untreated samples analyzed

\begin{tabular}{|c|c|c|c|c|c|c|c|c|c|c|}
\hline Sample & Fraction $(\mathbf{m m})$ & $\mathbf{Q}$ & $\mathbf{P 1}$ & $\mathbf{K f}$ & $\mathbf{M}^{*}$ & Px & Am & $\mathbf{C}$ & Py & H \\
\hline M1 & whole & 36 & 33 & 28 & 3 & & & & & \\
& $<0.063$ & 33 & 31 & 10 & 20 & & & 6 & & \\
\hline M2 & whole & 33 & 44 & 19 & 3 & & & 1 & & \\
& $<0.063$ & 14 & 38 & 14 & 18 & & 13 & 3 & & \\
\hline M3 & whole & 49 & 15 & 9 & 23 & 4 & & & & \\
& $<0.063$ & 18 & 58 & 10 & 8 & 3 & & & 3 & \\
\hline M4 & whole & 40 & 25 & 17 & 13 & 2 & & 3 & & \\
& $<0.063$ & 39 & 31 & 12 & 16 & 2 & & & & \\
\hline M5 & whole & 50 & 26 & 13 & 9 & & & 2 & & \\
& $<0.063$ & 32 & 20 & 15 & 20 & & & 13 & & \\
\hline M6 & whole & 17 & 11 & 11 & 1 & & & 59 & & 1 \\
& $<0.063$ & 13 & 26 & 9 & 10 & & 10 & 32 & & \\
\hline M7 & whole & 10 & 7 & 14 & 14 & & & 55 & & \\
\hline M8 & whole & 47 & 14 & 9 & 17 & 2 & 6 & 5 & & \\
& $<0.063$ & 38 & 20 & 20 & 11 & & & 11 & & \\
\hline
\end{tabular}

$\mathrm{Q}=$ quartz, $\mathrm{Pl}=$ plagioclase, $\mathrm{Kf}=$ potassium feldspar, $\mathrm{M}^{*}=$ mica (clay minerals for the $<0.063 \mathrm{~mm}$ fraction), $\mathrm{Px}=$ pyroxene, $\mathrm{Am}=$ amphibole, $\mathrm{C}=$ calcite, $\mathrm{Py}=$ pyrite, $\mathrm{H}=$ halite. 


\subsection{Geochemistry}

Chemical analysis results are presented in table 4 . All the clastic samples were geochemically classified according to Herron (1988) (Fig. 2), their depositional environment was defined according to Blatt et al. (1972) (Fig. 3) and the origin of the clastic materials was determined according to Roser and Korsch (1988) (Fig. 4). At these diagrams sample M7 is not projected because it is carbonate sediment (arkosic limestone).

Table 4 - Chemical composition (wt. \%) of the samples analyzed

\begin{tabular}{|c|r|r|r|r|r|r|r|r|r|r|}
\hline Sample & $\mathrm{SiO}_{2}$ & $\mathrm{Al}_{2} \mathbf{O}_{3 \mathbf{t}}$ & $\mathrm{Fe}_{2} \mathbf{O}_{3}$ & $\mathbf{C a O}$ & $\mathbf{M g O}$ & $\mathbf{K}_{2} \mathbf{O}$ & $\mathrm{Na}_{2} \mathbf{O}$ & $\mathbf{T i O}_{2}$ & $\mathbf{L O I}$ & Sum \\
\hline $\mathrm{M} 1$ & 77.20 & 10.93 & 2.34 & 1.55 & 0.29 & 3.04 & 1.87 & 0.38 & 2.53 & 100.13 \\
\hline $\mathrm{M} 2$ & 75.59 & 12.58 & 3.13 & 1.27 & 0.36 & 3.19 & 2.20 & 0.58 & 1.80 & 100.70 \\
\hline M3 & 65.20 & 17.10 & 5.98 & 1.22 & 1.48 & 3.26 & 2.14 & 0.90 & 3.13 & 100.41 \\
\hline M4 & 68.56 & 14.66 & 4.64 & 1.17 & 1.09 & 3.16 & 2.40 & 0.61 & 4.54 & 100.83 \\
\hline M5 & 65.55 & 14.18 & 4.93 & 3.15 & 1.05 & 2.43 & 2.24 & 0.95 & 6.01 & 100.49 \\
\hline M6 & 61.05 & 7.38 & 1.75 & 15.07 & 0.33 & 1.99 & 1.38 & 0.20 & 11.05 & 100.20 \\
\hline M7 & 33.41 & 9.44 & 3.72 & 25.24 & 1.24 & 1.57 & 1.14 & 0.44 & 23.52 & 99.72 \\
\hline M8 & 65.26 & 15.41 & 5.53 & 2.61 & 1.55 & 2.88 & 2.04 & 0.88 & 4.32 & 100.48 \\
\hline
\end{tabular}

$\mathrm{Fe}_{2} \mathrm{O}_{3 \mathrm{t}}=$ total iron, LOI=loss on ignition.

From figure 2 it is deduced that two samples (M3 and M8) may be classified as shales, two (M4 and M5) as wackes and three (M1, M2 and M6) as arkoses. The shale and wacke character of some samples (Fig. 2) is justified from the abundance of phyllosilicate minerals (micas + clay minerals) in their paragenesis (whole sample, table 3): M3 (23\%), M8 (17\%), M4 (13\%) and M5 $(9 \%)$, even though these samples are also rich in feldspars. Arkoses have continental origin, are formed through intense and rapid weathering and they are transported and deposited near the source area (Tsirambides 2004). According to Pettijohn et al. (1973) alkali feldspars are more abundant than plagioclases in the arkoses, a condition not valid in the studied samples.

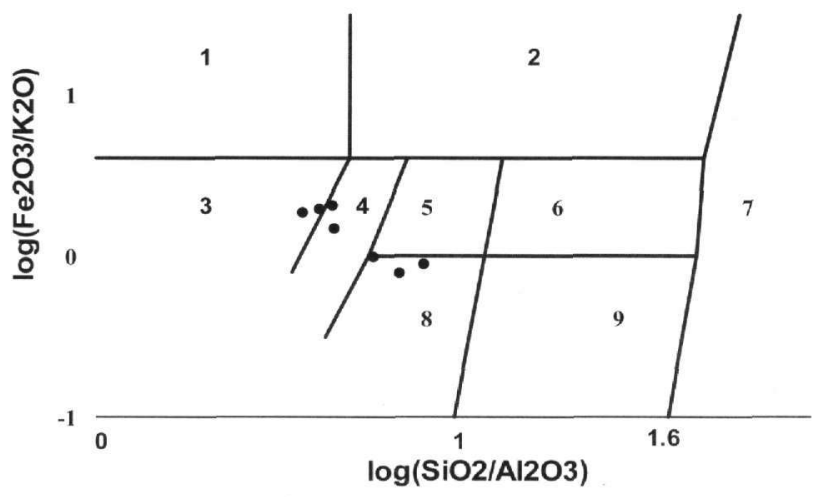

Figure 2 - Geochemical classification of terrigenous sandstones and shales (Herron 1988). $1=$ Fe-shale, 2 =Fe-sand, $3=$ shale, $4=$ wacke, 5 =litharenite, $6=$ =sublitharenite, $7=$ =uartz arenite, $8=$ arkose $\kappa a \imath$ 9=sub-arkose 


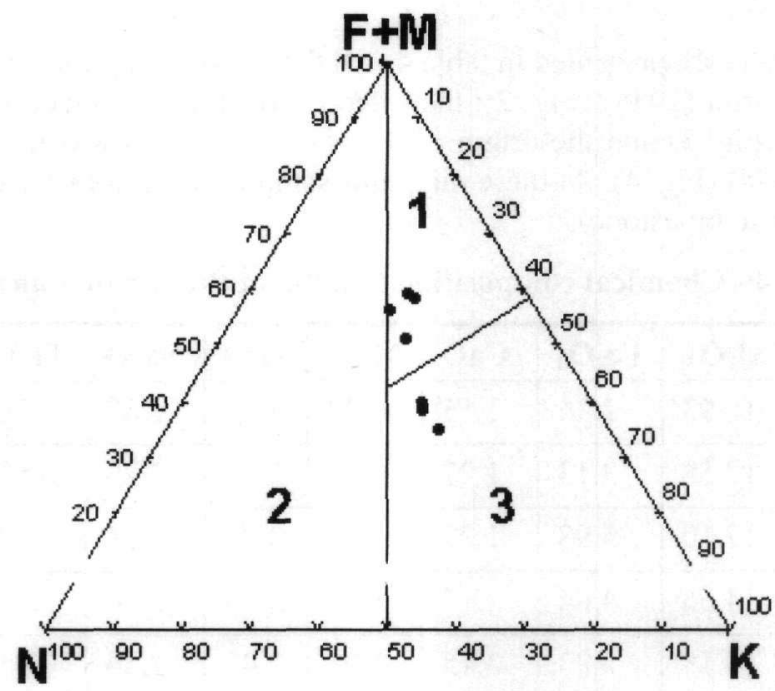

Figure 3 - Chemical composition of sandstones in relation to tectonic setting (Blatt et al. 1972). 1 =ferromagnesian sandstones, $2=$ sodic sandstones, $3=$ potassic sandstones.

$$
\mathrm{F}+\mathrm{M}=\mathrm{Fe}_{2} \mathrm{O}_{3 \mathrm{t}}+\mathrm{MgO}, \mathrm{N}=\mathrm{Na}_{2} \mathrm{O} \text { and } \mathrm{K}=\mathrm{K}_{2} \mathrm{O}
$$

In the ternary diagram of figure 3 four samples (M3, M4, M5 and M8), rich in mica and ferromagnesian minerals, are projected in the field of ferromagnesian sandstones and three samples (M1, M2 and M6), rich in feldspars, are projected in the field of potassic sandstones. The former were probably deposited at the craton margins getting their constituents from the weathering of the adjacent folded mountains. The potassic sandstones were probably deposited in tectonic basins inside the cratons (Blatt et al. 1972).

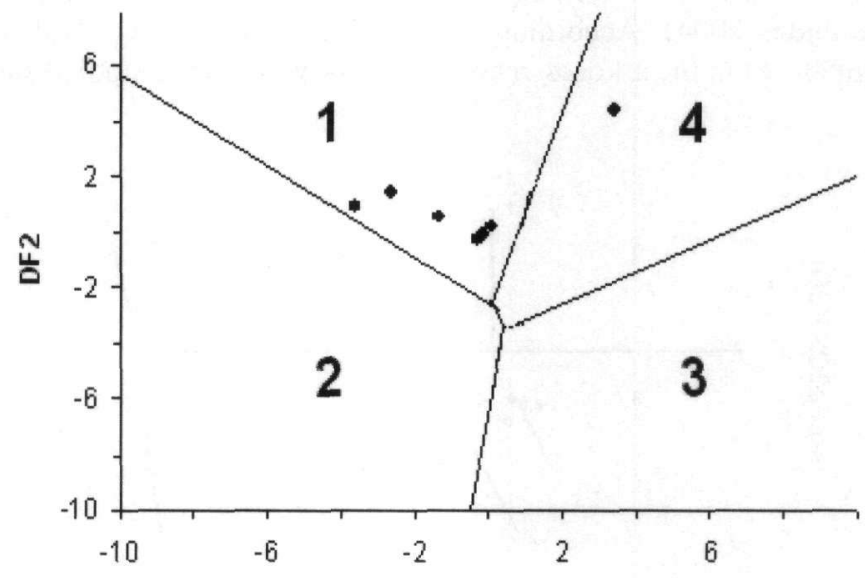

DF1

Figure 4 - Discriminant function diagram for the provenance signatures of sandstonemudstone suites (Roser and Korsch 1988).

$1=$ felsic igneous provenance, $2=$ quartzose sedimentary provenance, $3=$ mafic igneous provenance and $4=$ =intermediate igneous provenance.

$\mathrm{DF}_{1}=-1.773 \mathrm{TiO}_{2}+0.607 \mathrm{Al}_{2} \mathrm{O}_{3}+0.76 \mathrm{Fe}_{2} \mathrm{O}_{3 \mathrm{t}}-1.5 \mathrm{MgO}+0.616 \mathrm{CaO}+0.509 \mathrm{Na}_{2} \mathrm{O}-1.224 \mathrm{~K}_{2} \mathrm{O}-9.09$, $\mathrm{DF}_{2}=0.445 \mathrm{TiO}_{2}+0.07 \mathrm{Al}_{2} \mathrm{O}_{3}-0.25 \mathrm{Fe}_{2} \mathrm{O}_{3}-1.142 \mathrm{MgO}+0.438 \mathrm{CaO}+1.475 \mathrm{Na}_{2} \mathrm{O}+1.426 \mathrm{~K}_{2} \mathrm{O}-6.861$ 
In the diagram of figure 4 all the samples (except one) are projected into the field of felsic igneous provenance. Sample M6 is projected in the field of intermediate igneous provenance. The extended presence of Mesozoic igneous and metamorphic rocks in the broader area justifies this provenance signature for the studied red beds.

\section{Discussion}

The most likely source minerals for the formation of the studied red beds are quartz, feldspars, micas, and various Fe-Mg silicates, which are primary constituents of the Mesozoic basement igneous and metamorphic rocks predominating in the adjacent area. The poor sorting of the grains and their sub-angular morphology indicate that the red beds studied are texturally immature. In addition, the abundance of feldspars and Fe-Mg minerals reflects mineralogical immaturity.

The low relief and the long-lasting tectonic stability in the Chalkidiki district were essential for the

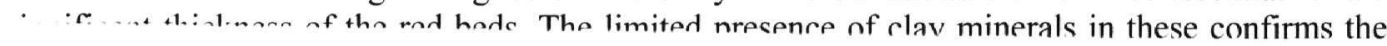
intense weathering of the parent rocks and the rapid transportation and deposition or une wedulesu materials close to the source area.

The formation of red beds may take place on low relief land under alternating wet and dry seasons. Such conditions prevail in the eastern Mediterranean region since Neogene (Nairn 1961). Even nowadays, in this area the climate is semi-arid with dry summers and mild winters.

In the poorly drained lowland of the studied area mean annual air temperature is $16.2{ }^{\circ} \mathrm{C}$, mean annual humidity $75 \%$, and mean annual rainfall $59.5 \mathrm{~cm}$ (Makrogiannis 1996).

For the terrigenous Neogene red beds of Northern Greece the paleoclimatic conditions during the time of their formation were warm and semiarid, characterized by wet and dry seasons. However, there is a controversial opinion about the prevailed climatic conditions; both the glacial (Koufos 1981, Vavliakis 1981) and the interglacial epochs (Marinos 1964) favoured the formation of the red beds in this period.

The textural and mineralogical characteristics of Moudania and Potidea red beds confirm that they were formed under warm and semiarid climate conditions.

\section{Conclusions}

The mineral constituents of the Neogene red beds are the weathering products of the parent rocks predominating in the adjacent area.

The red beds are texturally and mineralogically immature.

$>$ The low relief and the long-lasting tectonic stability in the Chalkidiki district were essential for the significant thickness (up to $30 \mathrm{~m}$ ) of the red beds.

$>$ The samples may be considered ferromagnesian and potassic sandstones.

The felsic igneous provenance signature is justified for most of the samples.

These sediments were formed on low relief land and under alternating wet and dry seasons.

The climate under which these Neogene red beds were formed was warm and semiarid.

\section{Acknowledgments}

Special thanks are due to Mr. A. Ziafetis, chemist, for the XRF analysis of the samples.

\section{References}

A.S.T.M., 1985. D2487, Classification of soils for engineering purposes, Ann. Book of ASTM Abstr., 04.08, 395-408. 
Blatt, H., Middleton, G., and Murray, R., 1972. Origin of sedimentary rocks, New Jersey, PrenticeHall, 634pp.

Chamley, H., 1989. Clay sedimentology, Berlin, Springer-Verlag, 663pp.

Cook, H.E., Johnson, P.D., Matti, J.C., and Zemmels, I., 1975. Methods of sample preparation and X-ray diffraction data analysis, Initial Reports, Deep Sea Drilling Project, 28, 999-1007.

Folk, R.L., Andrews, P.B., and Lewis, D.W., 1970. Detrital sedimentary rock classification and nomenclature for use in N. Zealand, N. Z. J. Geol. Geophys., 13, 937-968.

Herron, M.M, 1988. Geochemical classification of terrigenous sands and shales from core log data, J. Sed. Petrol., 58, 820-829.

I.G.M.E., 1978. Geological map of Greece, Vasilika sheet, scale 1:50.000, Athens.

Koufos, G., 1981. A new late Pleistocene (Wurmian) mammal locality from the basin of Drama (Northern Greece), Sci. Annals Fac. Phys. Mathem. Univ. Thessaloniki, 21, 129-148.

Makrogiannis, T., 1996. Kassadra Chalkidiki: reference to climate conditions, Climatologika, 10, $32 \mathrm{pp}$.

Marinos, G., 1964. Contribution to the learning of Pleistocene spreading in Macedonia, Sci. Annals Fac. Phys. Mathem. Univ. Thessaloniki, 9, 95-111.

Moore, D.M., and Reynolds, R.C., 1997. X-ray diffraction and the identification and analysis of clay minerals $-2^{\text {nd }} E d$, Oxford, Oxford University Press, 378pp.

Mountrakis, D., 1985. Geology of Greece, Thessaloniki, University Studio Press, 207pp.

Mountrakis, D., Syrides, G., Polymenakos, L., and Pavlides, S., 1993. The neotectonic structure of the eastern margin of Axios-Thermaikos graben in the area of western Chalkidiki (Central Macedonia), Bull. Geol. Soc. Greece, XXVIII(1), 379-395.

Nairn, A., 1961. Descriptive paleoclimatology, New York, Interscience, 560pp.

Pettijohn, F.J., Potter, P.E., and Siever, R., 1973. Sand and sandstone, New York, SpringerVerlag, 618pp.

Psilovikos, A., 1984. Lessons of sedimentology, Thessaloniki, University Publications, 131pp.

Psilovikos A., Koufos, G., and Syrides, G., 1987. The problem of red-beds in Northern Greece. Ann. Inst. Geol. Publ. Hung., LXX, 509-516.

Roser, B.P., and Korsch, R.J., 1988. Provenance signatures of sandstone-mudstone suites determined using discriminant function analysis of major-element data, Chem. Geol., 67, 119 139.

Schultz, L.G., 1964. Quantitative interpretation of mineralogical composition from X-ray and chemical data for the Pierre shale, U.S.G.S. Spec. Paper 391C, 33pp.

Sheldon, N.D., 2005. Do red beds indicate paleoclimatic conditions? A Permian case study. Palaeogeogr., Palaeocl., 228, 305-319.

Syrides, G., 1990. Lithostromatographic, biostromatographic and paleostromatographic study of the Neogene-Quaternary sedimentary formations of Chalkidiki Peninsula, PhD Thesis, Aristotle University, Thessaloniki, 243pp.

Tsirambides, A.E., 2004. Petrology of sedimentary rocks $-2^{\text {nd }}$ Ed., Thessaloniki, University Publications, 261pp. 
Vavliakis, E., 1981. Geomorphological and morphogenetic study of erosional surfaces, of karstic, glacial and periglacial formations of Menikion Mountain in Eastern Macedonia, PhD Thesis, Aristotle University, Thessaloniki, 192pp.

Vazoura, I., 1985. Study of the red beds of NW Chalkidiki, BSc Thesis, Aristotle University, Thessaloniki, 33pp.

Walker, T.R., 1976. Diagenetic origin of continental red beds. In H. Falke (ed.), The continental Permian in Central, West and South Europe. 240-282, Dordrecht, Reidel, 360pp.

Weaver, C.E., 1989. Clays, Muds, and Shales. Develop. Sedimentology 44. Elsevier, Amsterdam, 820pp. 